\title{
PENGARUH KEPUASAN KERJA DAN LINGKUNGAN KERJA TERHADAP SEMANGAT KERJA PEGAWAI UNIVERSITAS MUHAMMADIYAH PALANGKARAYA
}

\section{(The Effect of Job Satisfaction and Work Environment to the Spirit of the Employees of the University of Muhammadiyah Palangka Raya)}

\author{
IIN NURBUDIYANI \\ Program Studi Pendidikan Ekonomi Fakultas Keguruan dan IImu Pendidikan \\ Universitas Muhammadiyah Palangkaraya \\ JI. RTA Milono Km.1,5 Palangka Raya, Kalimantan Tengah 73111 \\ e-mail : iin_nurbudiyani@yahoo.co.id
}

\begin{abstract}
This research aims at knowing: (1) influence of working satisfaction on work spirit lecturer and employee University of Muhammadiyah Palangkaraya, (2) influence of fieldwork on work spirit lecturer and employee University of Muhammadiyah Palangkaraya, (3) influence of working satisfaction and fieldwork collectively on work spirit lecturer and employee University of Muhammadiyah Palangkaraya. This research is Ex Post Facto research because it only expresses already data without gives treatment or manipulation on research variable. Research is done in the office University of Muhammadiyah Palangkaraya RTA Milono Street Km 1,5 Palangka Raya Central Kalimantan. Variables will be researched: (1) Free Variable (Working Satisfaction and Fieldwork), and (2) Bound Variable (Work Spirit). Population is all lecturers and employees on the office University of Muhammadiyah Palangkaraya which amount more or less 100 people in this research. 100 populations were made group based on their work section, they are 65 lecturers and 35 section of personnels. Data collection uses questionnaire and documentation. Data was got explained in interval scale, to give real image, so it needs data description. This data is supplied in form of frequency distribution table, then to identify inclination each free variable and bound variable uses ideal average score (M) and ideal standard deviation (SD) then it is determined classification. Research result was: (1) Working satisfication of lecturer and employee on the office University of Muhammadiyah Palangkaraya had enough inclination, (2) There were significant influence of working satisfaction on work spirit, (3) There were significant influence of fieldwork on spirit work, (4) There were significant influence of working satisfaction and fieldwork collectively on working satisfaction.
\end{abstract}

Keywords: influence, satisfaction working, fieldwork, work spirit.

\begin{abstract}
ABSTRAK
Penelitian ini bertujuan untuk mengetahui: (1) pengaruh kepuasan kerja terhadap semangat kerja dosen dan pegawai Universitas Muhammadiyah Palangkaraya; (2) pengaruh lingkungan kerja terhadap semangat kerja dosen dan pegawai Universitas Muhammadiyah Palangkaraya; (3) pengaruh kepuasan kerja dan lingkungan kerja secara bersama-sama terhadap semangat kerja dosen dan pegawai Universitas Muhammadiyah. Penelitian ini merupakan penelitian Ex Post Facto karena hanya menguangkap data yang sudah ada tanpa memberikan perlakuan atau manipulasi terhadap variabel yang diteliti. Penelitian dilakukan di kantor Universitas Muhammadiyah Palangkaraya J. RTA Milono Km 1,5 Palangkaraya Kalimantan Tengah. Variabel yang akan diteliti adalah: (1) Variabel Bebas (Kepuasan Kerja dan Lingkungan Kerja) dan (2) Variabel Terikat (Semangat Kerja). Populasi dalam penelitian ini adalah semua dosen dan pegawai pada kantor Universitas Muhammadiyah Palangkaraya yang berjumlah kurang lebih 100 orang. Populasi berjumlah 100 tersebut dikelompokkan berdasarkan bagian kerjanya, yaitu dosen 65 orang dan bagian kepegawaian 35 orang. Pengumpulan data menggunakan angket dan dokumentasi. Data yang diperoleh dinyatakan dalam skala interval, untuk memberikan gambaran yang sesungguhnya, maka perlu adanya deskripsi data. Data ini disajikan dalam bentuk tabel distribusi frekuensi, kemudian untuk mengidentifikasikan kecenderungan masingmasing variabel bebas dan variabel terikat menggunakan skor rata-rata ideal (M) dan simpangan baku ideal (SD) yang selanjutnya ditentukan pengklasifikasian. Hasil penelitian adalah: (1) semangat kerja dosen dan pegawai kantor Universitas Muhammadiyah Palangkaraya mempunyai kecenderungan "cukup"; (2) terdapat pengaruh yang signifikan kepuasan kerja terhadap semangat kerja; (3) terdapat pengaruh yang signifikan lingkungan kerja terhadap semangat kerja; (4) terdapat pengaruh yang signifikan kepuasan kerja dan lingkungan kerja secara bersama-sama terhadap semangat kerja.
\end{abstract}

Kata kunci : pengaruh, kepuasan kerja, lingkungan kerja, semangat kerja 


\section{PENDAHULUAN}

Kelancaran pelaksanaan pembangunan nasional dan tugas-tugas pemerintah sangat ditentukan oleh kinerja lembaga-lembaga pemerintah yang ada. Sedangkan keberhasilan pengelolaan sebuah organisasi atau lembaga sebagian besar tergantung pada kegiatan pendayagunaan sumber daya manusia yang menjalankan organisasi tersebut. Meskipun dalam sebuah organisasi telah tersedia dana yang cukup besar dan peralatan yang digunakan sangat canggih serta modern, hal ini tidak akan ada artinya apabila sumber daya manusia yang ada tidak melaksanakan perannya dengan baik. Lembaga-lembaga pemerintah akan dapat menjalankan tugas dan fungsinya dengan baik atau tidak sangat ditentukan oleh aparatur negara atau yang lebih dikenal dengan sebutan pegawai. Oleh karena pegawai mempunyai peranan yang dominan dalam penyelenggaraan tugas pemerintah, maka mereka dituntut untuk memiliki kinerja yang baik. Kenyataan yang ada menunjukkan bahwa kinerja pegawai masih belum baik.

Kinerja pegawai yang tidak maksimal, salah satunya disebabkan karena salah penempatan kompetensi yang tidak sesuai bidang yang dilayani, ini akhirnya berimbas pada buruknya pelayanan kepada masyarakat. Selain itu kinerja pegawai yang tidak maksimal adalah karena keterbatasan kemampuan pegawai, juga adanya kelebihan jumlah pegawai. Kinerja seorang pegawai, salah satunya dapat dilihat dari semangat kerja yang dimilikinya. Kinerja seorang pegawai yang baik akan ditunjukkan dengan semangat kerja yang tinggi, dimana seorang pegawai yang memiliki semangat kerja yang tinggi akan memiliki disiplin kerja dan seamangat kerja sama yang tinggi. Sedangkan pegawai yang memiliki semangat kerja yang rendah akan cenderung menimbulkan berbagai permasalahan seperti malas, kurang disiplin, cepat merasa bosan dalam bekerja dan sebagainya.

Tinggi atau rendahnya semangat kerja pegawai sangat dipengaruhi oleh berbagai faktor. Faktor-faktor yang dapat mempengaruhi semangat kerja pegawai antara lain adalah kepuasan kerja dan lingkungan kerja. Kepuasan kerja mempengaruhi semangat kerja, karena apabila seorang pegawai merasa senang atau puas dalam bekerja maka akan membuat pegawai tersebut lebih betah di kantor, lebih giat dalam bekerja dan lebih taat pada peraturan yang berlaku. Lingkungan kerja yang baik juga akan sangat mendukung peningkatan semangat kerja pegawai. Lingkungan fisik kerja yang baik seperti: tata ruang yang baik, cahaya ruang yang cukup, udara yang sejuk, warna dinding ruangan yang baik, peralatan kantor yag tertata dengan baik, serta suasana yang tenang akan membuat pegawai lebih betah dikantor dan lebih bersemangat dalam melaksanakan tugastugasnya. Demikian juga dengan lingkungan sosial, apabila hubungan kerja terjalin dengan baik, komunikasi lancar dan suasana kekeluargaan dapat tercipta maka pegawai akan bekerja dengan penuh semangat.

Universitas Muhammadiyah Palangkaraya (UMP), sebagai salah satu lembaga pemerintah yang bergerak dalam bidang pendidikan dituntut untuk dapat melaksanakan tugas dan fungsinya dengan baik. Dalam aspek pendidikan Universitas Muhammadiyah Palangkaraya diharapkan dapat memberikan sumbangan dalam usaha 
mencerdaskan kehidupan masyarakat. Dimana pada masa sekarang, permasalahan pendidikan semakin kompleks, Universitas Muhammadiyah Palangkaraya dituntut untuk lebih dapat meningkatkan lagi perannya dalam memenmukan konsep-konsep penanganan masalah pendidikan melalui berbagai bentuk penelitian. Oleh karena itu untuk mewujudkannya diperlukan dosen dan pegawai yang memiliki kinerja yang baik, di mana salah satunya ditunjukkan dengan semangat kerja yang tinggi. Dalam melaksanakan pekerjaannya para dosen dan pegawai di Universitas Muhammadiyah Palangkaraya, terlihat ada yang kurang bersemangat dan belum maksimal. Dosen dan pegawai tampak bermalas-malasan, kurang disiplin, masih ada yang terlambat, sering tidak masuk, ataupun pulang sebelum waktunya. Dalam menyelesaikan pekerjaan para dosen dan pegawai tampak kurang giat, sering melakukan kegiatan yang tidak ada kaitannya dengan pekerjaan maupun sering keluar kantor. Berbagai masalah tersebut menunjukkan bahwa masih ada permasalahan dengan semangat kerja dosen dan pegawai pada Universitas Muhammadiyah Palangkaraya.

Faktor yang dapat mempengaruhi semangat kerja pegawai antara lain adalah kepuasan kerja. Masih adanya dosen dan pegawai pada Universitas Muhammadiyah Palangkaraya yang sering terlambat atau tidak masuk kerja, bermalas-malasan dalam bekerja, melakukan kegiatan yang tidak ada kaitannya dengan pekerjaan maupun sering keluar kantor, menunjukkan bahwa masih ada permasalahan dengan kepuasan kerja dosen dan pegawai pada Universitas Muhammadiyah Palangkaraya. Selain kepuasan kerja, faktor lain yang dapat mempengaruhi semangat kerja pegawai adalah lingkungan kerjanya. Letak kantor atau ruang kantor yang terpisah-pisah menyebabkan komunikasi antar pegawai dari masing-masing bagian menjadi kurang lancar. Hal ini menunjukkan bahwa lingkungan kerja pada Universitas Muhammadiyah Palangkaraya masih belum optimal. Mengingat semangat kerja pegawai sangat diperlukan dalam rangka mencapai tujuan sebuah organisasi, maka penelitian ini perlu dilakukan.

\section{KAJIAN PUSTAKA}

\section{Kepuasan Kerja}

Salah satu hal yang harus mendapat perhatian yang cukup besar dalam suatu organisasi adalah terciptanya kepuasan kerja pegawai, karena dengan adanya kepuasan kerja maka seseorang akan lebih bersemangat dalam bekerja sehingga dapat menunjang pencapaian tujuan organisasi. Kepuasan kerja adalah keadaan emosional karyawan di mana terjadi ataupun tidak terjadi titik temu antara nilai balas jasa kerja karyawan dengan tingkat nilai balas jasa yang memang diinginkan oleh karyawan yang bersangkutan (Susilo Martoyo, 1995: 132). Teori kepuasan kerja mengatakana bahwa, seseorang akan terpuaskan jika kondisi yang diinginkan sesuai dengan kondisi yang faktual. Jika ketidaksesuaian antara kondisi faktual dengan kondisi yang diinginkan semakin besar, maka semakin besar pula ketidak puasannya. Menurut Luthans yang dikutip oleh Bertina Sjabadhyni (2001: 464), ada enam dimensi yang berhubungan dengan pekerjaan yang mempengaruhi kepuasan kerja, yaitu: 
(1) pembayaran; (2) Work it-self; (3) promosi;

(4) supervisi; (5) kelompok kerja; dan

(6) kondisi kerja.

\section{Lingkungan Kerja}

Menurut Alex S. Nitisemito (1996: 109), yang disebut lingkungan kerja adalah segala sesuatu yang ada disekitar para pekerja dan yang dapat mempengaruhi dirinya dalam menjalankan tugas-tugas yang dibebankan. Siswanto Sastrohadiwiryo (2002: 32), menggunakan istilah iklim kerja untuk menyebutkan lingkungan kerja mengemukakan iklim kerja adalah kondisi situasi dan keadaan kerja yang menimbulkan tenaga kerja memiliki semangat dan moral/kegairahan kerja yang tinggi, dalam rangka meningkatkan produktivitas kerja sesuai dengan yang diharapkan. Pendapat tersebut dapat dikatakan bahwa lingkungan kerja adalah segala sesuatu yang ada di sekitar para pegawai yang dapat mempengaruhi dirinya dalam menjalankan tugastugas yang dibebankan. Lingkungan kerja dapat dibedakan menjadi dua, yaitu lingkungan fisik kerja dan lingkungan sosial. Lingkungan fisik meliputi: peralatan, bangunan kantor, perabot dan tata ruang (penerangan, udara, suara, warna), seperti juga kondisi jasmaniah tempat pegawai bekerja. Sedangkan lingkungan sosial intern tempat kerja berkaitan dengan tata hubungan intern. Tata hubungan intern ini meliputi tata hubungan intern menegak (vertikal) dan tata hubungan intern mendatar (horizontal). Tata hubungan vertikal adalah proses hubungan yang tejalain antara pimpinan dengan bawahan atau sebaliknya, misalnya perintah, petunjuk, pengaruh (dari pimpinan kepada bawahan) atau laporan pertanggung jawaban, pertanyaan, permohonan (dari bawahan kepada atasan). Hubungan ini dapat dilakukan dengan lisan maupun tertulis, formal maupun informal, tergantung pada kepentingannya. Sedangkan hubungan intern adalah kontak yang terjadi antar pegawai dalam suatu perusahaan dan para pegawai tersebut sama tingkat kedudukan dan sederajad (Didi Wahyu Sudirman, 1981: 56).

\section{Semangat Kerja}

Moekijat (1997: 135), menyatakan semangat kerja menunjukkan iklim dan suasana pekerjaan. Apabila para pekerja Nampak senang, optimis, ramah tamah maka mereka dikatakan mempunyai semangat yang tinggi/baik, sebaliknya apabila mereka nampak tidak puas, lekas marah, sering sakit, suka membantah, gelisah, pesimis maka reaksi-reaksi ini menunjukkan adanya semangat yang rendah/tidak baik. Maka dapat dikatakan bahwa semangat kerja adalah kemauan pegawai untuk melakukan pekerjaan dengan giat dan antusias sehingga pekerjaan dapat terselesaikan lebih cepat dan lebih baik. Faktor-faktor yang mempengaruhi semangat kerja menurut Taufik $A$ (1987: 156) adalah: (1) Hubungan yang harmonis antara pimponan dan bawahan; (2) Kepuasan para pegawai terhadap tugas dan pekerjaannya karena memperoleh tugas yang disukainya; (3) Terdapatnya suasana dan iklim kerja yang bersahabat dengan anggota-anggota lain organisasi; (4) Rasa kemanfaatan bagi tercapainya tujuan organisasi yang juga merupakan tujuan bersama; (5) Adanya tingkat kepuasan ekonomi dan kepuasan-kepuasan materiil lainnya; dan (6) Adanya ketenangan jiwa, jaminan kepastian serta perlindungan terhadap segala sesuatu yang dapat membahayakan diri pribadi dan karir dalam pekerjaan. 
Sedangkan unsur-unsur semangat kerja menurut Alex S. Nitisemito adalah: (1) Kepatuhan karyawan pada jam-jam kerja; (2) Kepatuhan karyawan pada perintah atasan serta taat pada tata tertib yang berlaku; (3) Penggunaan dan pemeliharaan bahan-bahan atau alat-alat perlengkapan dengan hati-hati; (4) Bekerja dengan mengikuti cara-cara kerja yang telah ditentukan perusahaan. Indikasi semangat kerja yang tinggi menurut Widjaja A.W (1990: 71), antara lain: (1) Rasa tanggung jawab dan disiplin kerja yang tinggi; (2) Rahasia jabatan yang dipegang teguh; (3) Membela kepentingan organisasi; (4) Kepentingan organisasi lebih diutamakan dari pada kepentingan sendiri; (5) Rasa solidaritas yang dengan semangat kerja sama yang tinggi; (6) Penghormatan dan kepercayaan terhadap atasan. Sedangkan Moekijat (1997: 142), mengemukakan indikasi semangat kerja yang rendah antara lain: (1) Kurang perhatian terhadap pekerjaan; (2) Kelelahan; (3) Kebosanan; (4) Perpindahan pegawai; (5) Keluhan; (6) Pemogokan; (7) Tingkat ketidak hadiran yang tinggi; (8) Masalah disiplin; (9) Pengurangan jumlah yang dihasilkan.

Siswanto Sastrohadiwiryo (2002: 285), mengemukakan bahwa secara umum, cara yang dapat ditempuh manajemen untuk meningkatkan moral atau semangat tenaga kerja melalui pendekatan sebagai berikut: (1) Memberikan kompensasu kepada tenaga kerja dalam porsi yang wajar tetapi tidak memaksakan kemampuan perusahaan; (2) Menciptakan iklim dan lingkungan kerja yang menggairahkan bagi semua pihak; (3) Memperhatikan kebutuhan yang berhubungan dengan spiritual tenaga kerja; (4) Perlu saat penyegaran sebagai media pengurangan ketegangan kerja dan memperkokoh rasa setia kawan antara tenaga kerja maupun manajemen; (5) Penempatan tenaga kerja pada posisi yang tepat; (6) Memperhatikan hari esok para tenaga kerja; (7) Peran serta tenaga kerja untuk menyumbangkan aspirasinya mendapatkan tempat yang wajar.

\section{HASIL DAN PEMBAHASAN}

\section{Hasil Penelitian}

Penelitian ini merupakan penelitian Ex Post Facto karena hanya menguangkap data yang sudah ada tanpa memberikan perlakuan atau manipulasi terhadap variabel yang diteliti. Seperti yang dikemukakan oleh Sugiyono bahwa penelitian Ex Post Facto adalah suatu penelitian yang dilakukan untuk meneliti peristiwa yang telah terjadi dan kemudian merunut kebelakang melalui data tersebut untuk menemukan faktor-faktor yang mendahului atau menentukan sebab-sebab yang mungkin atas peristiwa yang diteliti (Sugiyono, 2001: 3). Penelitian dilakukan di lingkungan kantor Universitas Muhammadiyah Palangkaraya Jl. RTA Milono Km 1,5 Palangkaraya Kalimantan Tengah. Variabel yang diteliti dalam penelitian ini meliputi :

a. Variabel Bebas (Independent Variable)

Variabel bebas kepuasan kerja dinyatakan dengan simbol $\mathrm{X} 1$, sedangkan variabel bebas lingkungan kerja dinyatakan dengan simbol $\mathrm{X} 2$.

b. Variabel Terikat (Dependent Variable) Variabel terikat semangat kerja dosen dan pegawai UM Palangkaraya dinyatakan dengan simbol Y. 


\section{Pembahasan}

Populasi dalam penelitian ini adalah semua dosen dan pegawai di lingkungan kantor Universitas Muhammadiyah Palangkaraya yang berjumlah kurang lebih 100 orang. Populasi berjumlah 100 orang tersebut dikelompokkan berdasarkan bagian kerjanya, yaitu dosen 65 orang dan bagian kepegawaian 35 orang. Pengumpulan data menggunakan angket berupa instrument dan dokumentasi. Data yang diperoleh dinyatakan dalam skala interval, untuk memberikan gambaran yang sesungguhnya, maka perlu adanya deskripsi data. Data ini disajikan dalam bentuk tabel distribusi frekuensi, kemudian untuk mengidentifikasikan kecenderungan masing-masing variabel bebas dan variabel terikat menggunakan skor rata-rata ideal (M) dan simpangan baku ideal (SD) yang selanjutnya ditentukan pengklasifikasian sebagai berikut:

$$
\begin{array}{ll}
(M+1 S D) \text { ke atas } & =\text { Tinggi } \\
(M-1 S D) \text { sampai }(M+1 S D) & =\text { Cukup } \\
(M-1 S D) \text { ke bawah } & =\text { Kurang }
\end{array}
$$

Penelitian ini menemukan adanya kecenderungan semangat kerja pegawai adalah "cukup". Berdasarkan hasil analisis diketahui skor rata-rata semangat kerja sebesar 37,45 . Dilihat dari kategori yang digunakan maka semangat kerja pegawai memiliki kecenderungan baik karena skor rata-rata tersebut termasuk dalam kelas interval 36,00 - 38,00 dengan kategori baik. Jika dilihat distribusi kecenderungan dari 100 responden sebanyak 96 orang atau $96,00 \%$ tergolong dalam kategori semangat kerjanya "cukup" dan termasuk dalam kategori "tinggi" sebanyak 4 orang atau $4,00 \%$.
Hasil ini menunjukkan adanya pengaruh yang signifikan kepuasan kerja terhadap semangat kerja. Hal ini ditunjukkan oleh t hitung sebesar 5,686 dengan probabilitas 0,000, sedangkan $t$ tabel pada taraf signifikansi $5 \%$ adalah 1,980. Oleh karena $t$ hitung lebih besar dari $t$ tabel dan signifikansi $t$ hitung kurang dari 0,05 maka dapat disimpulkan bahwa kepuasan kerja berpengaruh terhadap semangat kerja.

Penelitian ini juga menemukan ada pengaruh yang signifikan lingkungan kerja terhadap semangat kerja, karena diperoleh t hitung sebesar 5,279 dengan signifikansi 0,000 , sedangkan t tabel pada taraf signifikansi $5 \%$ adalah 1,980 . Oleh karena thitung lebih besar dari t tabel dan signifikansi t hitung kurang dari 0,05 maka dapat disimpulkan bahwa lingkungan kerja berpengaruh cukup besar terhadap semangat kerja

Adapun pengaruh kedua variabel yaitu kepuasan kerja dan lingkungan kerja juga menunjukkan pengaruh yang signifikan. Hal ini dapat dilihat dari $\mathrm{F}$ hitung yang diperoleh sebesar 4,973 dengan probabilitas 0,000 sedangkan F tabel pada taraf signifikansi $5 \%$ adalah 3.09 . Oleh karena $\mathrm{F}$ hitung lebih besar dari $\mathrm{F}$ tabel dan probabilitas $\mathrm{F}$ hitung kurang dari 0,05 maka dapat disimpulkan adanya pengaruh yang signifikan antara kepuasan kerja dan lingkungan kerja terhadap semangat kerja.

\section{KESIMPULAN}

Berdasarkan hasil penelitian dan pembahasan maka disimpulkan bahwa :

a. Semangat kerja dosen dan pegawai di lingkungan kantor Universitas Muhammadiyah 
Palangkaraya mempunyai kecenderungan kategori "cukup".

b. Terdapat pengaruh yang signifikan kepuasan kerja dosen dan pegawai di lingkungan kantor Universitas Muhammadiyah Palangkaraya terhadap semangat kerja.

c. Terdapat pengaruh yang signifikan lingkungan kerja dosen dan pegawai di kantor Universitas Muhammadiyah Palangkaraya terhadap semangat kerja.

d. Terdapat pengaruh yang signifikan kepuasan kerja dan lingkungan kerja secara bersamasama terhadap semangat kerja dosen dan pegawai kantor Universitas Muhammadiyah Palangkaraya.

\section{DAFTAR PUSTAKA}

Alex S. Nitisemito. 1996. Manajemen Personalia. Jakarta: Rineka Cipta.

Bertina Sjabadhyni, et. A. 2001. Pengembangan Kualitas SDM dari Perspektif PIO. Penerbit Bagian Psikologi Industri dan Organisasi Fakultas Psikologi Universitas Indonesia. Depok.

Didi Wahyu Sudirman. 1981. Pengetahuan Administrasi Kantor. Yogyakarta: Liberty.

Moekijat. 1982. Manajemen Perkantoran Tata Laksana Kantor. Bandung: Alumni.

Susilo Martoyo. 1996. Manajemen Sumber Daya Manusia. Yogyakarta: BPFE.

Sutrisno Hadi. 1994. Analisis Regresi. Yogyakarta: Andi Offset.

Siswanto Sastrohadiwiryo. 2002. Manajemen Tenaga Kerja Indonesia Pendekatan Administrasi dan Operasional. Jakarta: Bumi Aksara.

Sugiyono. 2002. Metode Penelitian Bisnis. Bandung: Alfabeta.
Taufik, A. 1987. Korelasi dan Analisis Regresi Ganda. Yogyakarta: Nur Cahyo.

Widjaja, A.W. 1990. Administrasi Suatu Pengantar. Jakarta: Rajawali 